\title{
COMPARISON BETWEEN HOSPITAL INPATIENT COST AND INA- CBGS TARIFF OF INPATIENT CARE IN THE NATIONAL HEALTH INSURANCE SCHEME IN SOLO, BOYOLALI AND KARANGANYAR DISTRICTS, CENTRAL JAVA
}

\author{
Indriyati Oktaviano Rahayuningrum ${ }^{1)}$, Didik Gunawan Tamtomo²), \\ Arief Suryono3) \\ 1)Faculty of Medicine, Muhammadiyah University, Surakarta \\ 2)Faculty of Medicine, Sebelas Maret University \\ 3)Faculty of Law, Sebelas Maret University
}

\begin{abstract}
Background: Hospital has an important referral system role in the implementation on the National Health Insurance (NHI) Scheme. BPJS Kesehatan (NHI Implementing Agency) pays hospitals by Indonesian Case Based Groups (INA-CBGs) method. This payment method may potentially cause loss or profit to the hospital, when there is discrepancy between hospital inpatient cost and INA-CBGs tariff of inpatient care. This study aimed at investigating the discrepancy between hospital inpatient cost and INA-CBGs tarif of inpatient care and the determinants of hospital inpatient cost.
\end{abstract}

Subjects and Method: This was an analytic and observational study cross sectional approach. This study was conducted in 2 publichospitals and 2 private hospitals, from October to December 2016. A total sample of 100 inpatients was selected at random for this study. The dependent variables were hospital inpatient cost and INA-CBGs tariff. The independent variables included hospital type, inpatients class, disease severity, use of ICU, and length of stay. The data were analyzed by a multiple linear regression model.

Results: Averagehospital inpatient cost (mean= Rp. 2,280,000; $\mathrm{SD}=1,690,000)$ was lower than average INA-CBGs (mean $=$ Rp. 3,060,000). There were negative relationships between hospital type, inpatient class, disease severity, and hospital inpatient cost. Private hospital inpatient cost $(b=-5.66 ; 95 \% \mathrm{CI}=-1.20$ to 0.06 ; $\mathrm{p}=0.078$ ) was lower than public hospital inpatient cost. Class 2 inpatient care $(b=-0.34 ; 95 \% \mathrm{CI}=-1.09$ to $0.41, \mathrm{p}=0.371)$, class 3 inpatient care $(\mathrm{b}=-0.50 ; 95 \%$ $\mathrm{CI}=-1.23$ to $0.23, \mathrm{p}=0.177)$, had lower hospital inpatient cost than class 1 inpatient care.Severe disease $(b=-0.12 ; 95 \% \mathrm{CI}=-1.95$ to $1.71 ; \mathrm{p}=0.894)$ had lower hospital inpatient cost than mild disease, although it was not statistically significant. There were positive relationships between use of ICU, disease severity, length of stay, and hospital inpatient cost. Using ICU $(b=1.58 ; 95 \% \mathrm{CI}=$ 0.76 to $2.4 ; \mathrm{p}=<0.001$ ) had higher hospital inpatient cost than not using ICU. Moderate disease severity $(b=0.55 ; 95 \% \mathrm{CI}=-0.20$ to $1.30 ; \mathrm{p}=0.150)$ had higher hospital inpatient cost than mild disease. Longer stay $(b=0.27 ; 95 \% \mathrm{CI}=0.08$ to $0.45 ; \mathrm{p}=0.005$ ) had higher hospital inpatient cost than shorter stay.

Conclusion: Average hospital inpatient cost was lower than average INA-CBGs tariff. Hospital type, use of ICU, and length of stay, are important determinants of hospital inpatient cost.

Keywords: hospital inpatient cost, INA-CBGs tariff, determinant

Correspondence: Indriyati Oktaviano Rahayuningrum. Faculty of Medicine, Muhammadiyah University Surakarta. Email: indriyatioktaviano@yahoo.com 